Vol.3 No.2 Hal. 09 - 16

September 2020
BEST JOURNAL

(Biology Education,science \& Technolog̉y)

Fakultas Keguruan dan IImu Pendidikan
ISSN (Print) : $2614-8064$

ISSN (Online): $2654-4652$

\title{
Pengaruh Penyuluhan Terhadap Pengetahuan dan Sikap Tentang Penyakit Menular Seksual (PMS) Pada Siswa Kelas XI IPA SMA Banuhampu Kabupaten Agam Sumatera Barat Tahun 2018
}

\author{
Aulia Fuad, Saiful Batubara \\ Fakultas Kedokteran Universitas Islam Sumatera Utara \\ aulia.fuad.001@gmail.com , Saifulbatubara24@gmail.com
}

\begin{abstract}
ABSTRAK
Penyakit Menular Seksual (PMS) atau dikenal juga dengan infeksi menular seksual (IMS) Merupakan infeksi yang umumnya ditularkan melalui hubungan seks yang tidak aman, Penelitian ini dilakukan untuk mengetahui Pengaruh Penyuluhan Terhadap Pengetahuan dan Sikap tentang Penyakit Menular Seksual pada siswa kelas XI IPA di SMA Banuhampu Kabupaten Agam Sumatera Barat tahun 2018. Penelitian ini adalah Jenis penelitian kuantitatif. Dengan desain penelitian kuasi eksprimental. Populasi penelitian ini terdiri dari 90 responden dengan sampel sebanyak 37 pada kelompok eksperimen dan 37 pada kelompok kontrol. Pengolahan data dengan menggunakan komputerisasi. Kemudian data di Analisa secara Univariat dan Bivariat dengan $u j i$ $T$-Test. Hasil penelitian ini didapatkan pada kelompok eksperimen. Hasil pengujian $t$-test paired menunjukkan nilai signifikansi sebesar 0,000 untuk tingkat pengetahuan dan tingkat sikap sehingga dapat kita nyatakan bahwa terdapat pengaruh penyuluhan terhadap tingkat pengetahuan dan tingkat sikap. Bahwa terdapat pengaruh penyuluhan terhadap tingkat pengetahuan dan sikap. Untuk itu diharapkan Penelitian ini dapat digunakan sebagai tambahan informasi bagi pelajar supaya dapat menghindari faktor resiko penyakit menular seksual (PMS).
\end{abstract}

Kata Kunci : Penyakit Menular Seksual (PMS)

\begin{abstract}
Sexually transmitted diseases (STDs) / Contangius Sexual Desease (PMS) or also known as sexually transmitted infections (STIs) are infections that are generally transmitted through unsafe sex. This study was conducted to determine the effect of education on knowledge and attitudes about sexually transmitted diseases in class XI IPA students in SMA Banuhampu Agam Regency, West Sumatra in 2018. This research is a type of quantitative research. With a quasi experimental research design. The study population consisted of 90 respondents with a sample of 37 in the experimental group and 37 in the control group. Data processing using computerization. Then the data were analyzed by Univariate and Bivariate by means of the T-Test. The results of this study were obtained in the experimental group. The results of the paired t-test show a significance value of 0.000 for the level of knowledge and the level of attitudes so that we can state that there is an effect of extension on the level of knowledge and the level of attitudes. That there is an influence of extension on the level of knowledge and attitudes. For this reason, it is hoped that this research can be used as additional information for students in order to avoid risk factors for sexually transmitted diseases (STDs)
\end{abstract}

Keywords : Contangius Sexual Desease (PMS) 
Fuad A, Batubara S : Pengaruh Penyuluhan Terhadap Pengetahuan dan Sikap Tentang Penyakit Menular Seksual (PMS) Pada Siswa KElas XI IPA SMA Banuhampu Kabupaten Agam Sumatera Barat Tahun 2018

\section{PENDAHULUAN}

\section{Latar Belakang}

Remaja merupakan suatu usia waktu individu mulai menunjukkan tanda-tanda seksual sekundernya mencapai kematangan seksual, lalu mengalami perubahan fisik, kognitif, psikologis dan pola identifikasi dari masa kanak-kanak menjadi dewasa, setelah itu terjadilah peralihan dari ketergantungan sosial ekonomi menuju keadaan yang relatife lebih mandiri, menjadi terintegrasi ke dalam masyarakat dewasa, serta individu tidak merasa bahwa dirinya itu berada di bawah tingkat orang yang lebih tua melainkan merasa sama (Wardhani, 2012) Sa'id (2015), membagi usia remaja menjadi tiga fase sesuai tingkat umur yang dilalui oleh remaja. Fase remaja awal yaitu remaja yang rentang usianya 12 hingga 15 tahun. Umumnya remaja tengah berada di masa sekolah menengah pertama (SMP), fase remaja pertengahan yaitu remaja yang rentang usianya 15 hingga 18 tahun. Umumnya remaja tengah berada di masa sekolah menengah atas (SMA), fase remaja akhir yaitu remaja yang rentang usianya sekitar 18 hingga 21 tahun. Remaja pada usia ini umumnya tengah berada pada usia pendidikan di perguruan tinggi, atau bagi remaja yang tidak melanjutkan ke perguruan tinggi, mereka mulai bekerja dan membantu menafkahi anggota keluarga. Pusat data dan informasi Kementrian Kesehatan Republik Indonesia (KemenKes RI), 2018 terdapat 166.606.825 jumlah usia produktif di Indonesia. Sedangkan berdasarkan data dari Badan Pusat Statistik Kota Padang tahun 2018, terdapat 174.663 jumlah remaja di Kota Padang. Sedangkan data dari Badan Pusat Statistik Kabupaten Agam tahun 2018 terdapat 490.050 jumlah remaja di Kabupaten Agam. Menurut SDKI (Survei Demografi Kesehatan Indonesia) tahun 2014 di Indonesia, pravelensi PMS terjadi sebanyak 5608 kasus. Menurut laporan dari data Kemetrian Kesehatan Kota Padang (KemenKes Kota Padang) tahun 2018 terdapat 89 kasus. Menurut penelitian yang telah dilakukan oleh Putri Arom Cosmeticawaty (2014) di SMA Negeri 2 Banguntapan Bantul Yogyakarta di dapatkan hasil mununjukkan tingkat pengetahuan sebelum di beri penyuluhan dalam kategori cukup pada eksperimen $50,0 \%$ maupun kontrol 47,5\%, begitu juga pretest sikap eksperimen mayoritas cukup 75,0\% dan kontrol cukup (72,9\%). Tingkat pengetahuan posttest pada eksperimen meningkat jadi baik sebesar $76,7 \%$, sedangkan kontrol 55,9\% tetap cukup. Sikap eksperimen setelah penyuluhan yaitu $81,7 \%$ baik, dan kontrol tetap cukup $(69,5 \%)$.

\section{Perumusan Masalah}

Kurangnya informasi dan pengetahuan seseorang akan dapat berdampak terhadap pembentukan sikap seseorang. Pengetahuan yang baik dapat mempengaruhi seseorang bersikap positif. Sebaliknya pengetahuan yang kurang dapat mempengaruhi seseorang itu bersikap negatif. Sikap merupakan reaksi atau respon seseorang yang masih tertutup terhadap suatu stimulus atau objek (Notoatmodjo, 2013). Pada masa remaja mereka itu cenderung memiliki sikap ingin tahu yang lebih besar, di mana mereka memiliki naluri yang sangat tinggi untuk coba-coba. Rasa ingin tahu yang lebih besar ini menyebabkan mereka itu lebih mudah terpengaruhi oleh kebiasaan sehari-hari di lingkungan tempat mereka bergaul. Sikap remaja zaman sekarang ini banyak yang melanggar norma-norma yang telah ada, ketika remaja itu terpengaruh kedalam pergaulan yang tidak baik itu akan berdampak kepada sikap remaja itu sendiri, baik apa tidaknya sikap remaja itu. Hasil SDKI (Survei Demografi Kesehatan Indonesia) 2018 KRR (Kesehatan Reproduksi Remaja) menunjukkan bahwa pengetahuan remaja tentang kesehatan reproduksi belum memadai yang dapat dilihat dengan hanya 35,3\% remaja perempuan dan 31,2\% remaja laki-laki usia 15-19 mengetahui bahwa perempuan dapat hamil dengan satu kali berhubungan seksual. Begitu pula gejala PMS kurang diketahui oleh remaja. 
Fuad A, Batubara S : Pengaruh Penyuluhan Terhadap Pengetahuan dan Sikap Tentang Penyakit Menular Seksual (PMS) Pada Siswa KElas XI IPA SMA Banuhampu Kabupaten Agam Sumatera Barat Tahun 2018

\section{Tujuan Penelitian}

Berdasarkan informasi yang di dapat, di SMA Banuhampu Kabupaten Agam sendiri pada beberapa tahun sebelumnya didapati siswi mengalami kasus kehamilan yang tidak diinginkan sehingga dengan terpaksa siswi tersebut tidak bisa melanjutkan sekolah dengan alasan melanjutkan kehamilan dan harus menikah. Ini berarti siswi itu melakukan hubungan seks bebas. Seks bebas adalah hubungan seksual secara bebas, tanpa di batasi oleh aturanaturan. Ini membuktikan bahwa masih kurangnya pengetahuan siswa tentang dampak negative dari seks pranikah yang paling meresahkan masyarakat salah satunya Adalah PMS. Banyak hal yang melatar belakangi kejadian-kejadian tersebut, salah satunya adalah kurangnya informasi tentang seks bebas. Rasa malu membicarakan masalah seks pada orang tua, sehingga menyebabkan remaja tersebut mencari sumber informasi lain. Informasi seseorang tentang sesuatu hal, bisa ditingkatkan melalui berbagai cara diantaranya dengan penyuluhan. Hasil studi pendahuluan yang dilakukan pada 10 orang pelajar yang terdiri dari 5 orang laki-laki dan 5 orang perempuan, didapatkan 7 dari 10 orang pelajar tidak mengetahui tentang PMS, sedangkan 3 diantaranya mengatakan pernah mendengar tentang PMS. Dari survei awal maka peneliti ingin melakukan penelitian tentang "Pengaruh Penyuluhan Terhadap Pengetahuan dan Sikap tentang Penyakit Menular Seksual pada siswa kelas XI di SMA Banuhampu Kabupaten Agam Sumatera Barat tahun 2018.

\section{Manfaat Penelitian}

Pengetahuan (knowledge) merupakan hasil tahu dari manusia terhadap sesuatu, atau segala perubahan dari manusia untuk memahami suatu objek tertentu. Pengetahuan dapat berwujud barang-barang baik lewat indra maupun lewat akal, dapat pula objek yang dipahami oleh manusia berbentuk ideal atau bersangkutan dengan masalah kejiwaan (Notoatmodjo, 2013). PMS Adalah sekelompok infeksi yang ditularkan melalui hubungan seksual. Kebanyakan PMS dapat ditularkan melalui hubungan seksual antara penis, vagina, anus dan mulut (Zakaria, 2016).

\section{METODE PENELITIAN}

Penelitian ini berjenis kuantitatif dengan desain penelitian kuasi eskperimental dengan pendekatan pre \& post study yang dilakukan pada pertengahan bulan juli - agustus 2018. Populasi penelitian ini adalah siswa kelas XI IPA di SMA Banuhampu Kabupaten Agam sebanyak 90 orang dan di dapatkan sampel 74 orang di bagi menjadi dua kelompok yaitu 37 pada kelompok kontrol dan 37 pada kelompok eksperimen. Kemudian dengan menggunakan kuesioner dan penyuluhan pada kelompok eksperimen. Data dianalisis secara univariat dan bivariate dengan komput menggunakan Uji-T Paired Test.

\section{HASIL DAN PEMBAHASAN}

Gambaran Umum Lokasi Penelitian

Sekolah Menengah Atas Banuhampu Kabupaten Agam merupakan salah satu Sekolah Menengah Atas yang ada di Kabupaten Agam yang beralamat Padang Lua, Kecamatan Banuhampu, Kabupaten Agam, Sumatera Barat. Banyak hal yang melatar belakangi kejadian-kejadian PMS, salah satunya adalah kurangnya informasi tentang seks bebas. Rasa malu membicarakan masalah seks pada orang tua, sehingga menyebabkan remaja tersebut mencari sumber informasi lain. Informasi seseorang tentang sesuatu hal, bisa ditingkatkan melalui berbagai cara diantaranya dengan penyuluhan. Kurangnya informasi tentang Seks bebas yang diketahui remaja dapat berdampak negatif terhadap perkembangan remaja di masa yang akan datang, salah satu contoh akibat kurangnya pengetahuan remaja serta seks bebas dapat membuat remaja bergonta ganti pasangan karena hal tersebut dapat 
Fuad A, Batubara S : Pengaruh Penyuluhan Terhadap Pengetahuan dan Sikap Tentang Penyakit Menular Seksual (PMS) Pada Siswa KElas XI IPA SMA Banuhampu Kabupaten Agam Sumatera Barat Tahun 2018

menimbulkan sikap negatif, jika hal ini tidak dapat di atasi maka dapat mengakibatkan PMS. Berdasarkan fenomena yang terjadi di atas peneliti ingin melakukan penelitian di SMAN Banuhampu tentang Pengaruh Penyuluhan Terhadap Pengetahuan dan Sikap tentang Penyakit Menular Seksual. Hal ini bertujuan untuk melihat sejauh mana pengetahuan dan sikap siswa/siswi di SMAN Banuhampu, selain itu peneliti tertarik melakukan penelitian di SMA tersebut untuk meningkatkan pengetahuan dan sikap siswa/siswi tentang peyakit meular seksual agar kejadian di masa lampau tidak terulang kembali.

\section{A. Karakterisitik Responden}

Karakteristik Responden Berdasarkan Umur dan Jenis Kelamin Di SMAN Banuhampu, Kabupaten Agam.

\begin{tabular}{|l|l|l|l|l|}
\hline No & \multicolumn{2}{|l|}{ Karakteristik Responden } & $(\mathbf{f})$ & $\begin{array}{l}\text { Presentase } \\
(\%)\end{array}$ \\
\hline & Umur & & & \\
\hline 1 & Kelompok & $<15$ tahun & 3 & 8,1 \\
& Eksperimen & $15-20$ tahun & 34 & 91,9 \\
\hline 2 & Kelompok & $<15$ tahun & 4 & 10,8 \\
& Kontrol & $15-20$ tahun & 33 & 89,2 \\
& Jenis & & & \\
& Kelamin & & & \\
\hline 1 & Kelompok & Perempuan & 21 & 56,8 \\
& Eksperimen & Laki-Laki & 16 & 43,2 \\
\hline 2 & Kelompok & Perempuan & 21 & 56,8 \\
& Kontrol & LakLaki & 16 & 43,2 \\
& & & & \\
\hline
\end{tabular}

Dapat dilihat bahwa dari karakteristik umur responden mayoritas responden berumur 15-20 tahun yaitu $(91,9 \%)$ pada kelompok eksperimen dan $(89,2 \%)$ pada kelompok kontrol sedangkan dilihat karakteristik berdasar jenis kelamin yaitu $(56,8 \%)$ perempuan baik pada kelompok eksperimen maupun pada kelompok kontrol.

Tabel 4.1 Rata-Rata Tingkat Pengetahuan Tentang PMS Pada Siswa Kelas XI di SMA Negeri Banuhampu Kabupaten Agam. Sebelum Dilakukan Penyuluhan

\begin{tabular}{|c|c|c|}
\hline \multicolumn{3}{|c|}{ Tingkat } \\
\hline $\begin{array}{l}\text { Analisis } \\
\text { Univariat }\end{array}$ & \multicolumn{2}{|c|}{$\begin{array}{l}\text { Pengetahuan } \\
\text { Tentang PMS }\end{array}$} \\
\hline \multicolumn{2}{|c|}{$\overline{\text { Kelompok }}$} & Eksperimen \\
\hline & & 56,21 \\
\hline & lian & 60,00 \\
\hline c. & & 11,91 \\
\hline & & 53,33 \\
\hline & imum & 26,67 \\
\hline & simum & 80.00 \\
\hline
\end{tabular}


Fuad A, Batubara S : Pengaruh Penyuluhan Terhadap Pengetahuan dan Sikap Tentang Penyakit Menular Seksual (PMS) Pada Siswa KElas XI IPA SMA Banuhampu Kabupaten Agam Sumatera Barat Tahun 2018

\begin{tabular}{|l|l|}
\hline Kelompok Kontrol & \\
\hline a. Mean & 58,01 \\
\hline b. $\quad$ Median & 60,00 \\
c. $\quad$ SD & 13,03 \\
\hline d. $\quad$ Range & 53,33 \\
\hline e. $\quad$ Minimum & 26,67 \\
\hline f. $\quad$ Maksimum & 80,00 \\
\hline
\end{tabular}

Berdasarkan tabel 4.1 diatas menunjukkan bahwa berdasarkan hasil statistik deskriptif tingkat pengetahuan tentang PMS sebelum dilakukan penyuluhan pada kelompok Eksperimen didapatkan rata-rata yaitu sebesar 56,21, median 60,00, standar deviasi 11,91, range 53,33 , nilai minimum 26,67 dan maksimun 80,00 . Sedangkan rata-rata pada kelompok kontrol yaitu sebesar 58,01, median 60,00, standar deviasi 13,03, range 53,33, nilai minimum 26,67 dan nilai maksimum 80,00.

\section{Analisis Bivariat}

\section{Uji-T Paired Test}

Untuk melakukan uji statistik bivariat menggunakan uji-t paired test harus dipenuhi syarat normalitas data yaitu sebagai berikut:

Uji normalitas data bertujuan untuk mengetahui apakah penyetaran data merata sesuai dengan kurva normal (Syarifudin, 2010). Normalitas data diuji dengan menggunakan uji kolmogorovsmirnov Pembacaan hasil uji normalitas kolmogorov-smirnov berdasarkan nilai dari pearson value (asymp. sig), yaitu jika nilai $P$-Value $>0,05$ maka data berdistribusi normal dan jika nilai $P$-Value $<0,05$ maka data tidak berdistribusi normal.

\section{PEMBAHASAN}

\section{A. Analisa Univariat}

\section{Rata-Rata Tingkat Pengetahuan Tentang PMS Pada Siswa Kelas XI Di SMA Banuhampu Kabupaten Agam Sebelum Dilakukan Penyuluhan}

Berdasarkan tabel 4.1 didapatkan bahwa rata-rata tingkat pengetahuan tentang PMS sebelum dilakukan penyuluhan pada kelompok Eksperimen yaitu sebesar 56,21 dengan standar deviasi 11,91 sedangkan rata-rata pada kelompok kontrol yaitu sebesar 58,01 dengan standar deviasi 13,03. Diketahui pula dari data diatas bahwa perbedaan rata-rata pada kelompok kontrol dan eksperimen sebelum dilakukan penyuluhan tidak jauh berbeda. Hipotesis yang paling mungkin menjelaskan keadaan ini adalah pengetahuan responden itu sendiri. Sesuai dengan observasi yang dilakukan oleh peneliti pada responden kelompok eksperimen dan kelompok kontrol, diantara kelompok eksperimen dan kontrol masih menjawab beberapa pertanyaan yang salah, serta perbedaan jawaban dari kelompok kontrol dan eksperimen hampir sama seputar pengetahuan tentang PMS. Hal ini didukung oleh hasil penelitian yang telah dilakukan oleh Putri Arom Cosmeticawaty (2014) di SMA Negeri 2 Banguntapan Bantul Yogyakarta di dapatkan hasil mununjukkan tingkat pengetahuan sebelum di beri penyuluhan dalam kategori cukup pada eksperimen 50,0\% maupun kontrol 47,5\%. Hal diatas sesuai dengan teori yang menyatakan bahwa pengetahuan merupakan hasil pengindraan manusia, atau hasil tahu seseorang terhadap objek melalui indra yang dimilikinya (mata, hidung, telinga, dan sebagainya). Dengan sendirinya, pada waktu 
Fuad A, Batubara S : Pengaruh Penyuluhan Terhadap Pengetahuan dan Sikap Tentang Penyakit Menular Seksual (PMS) Pada Siswa KElas XI IPA SMA Banuhampu Kabupaten Agam Sumatera Barat Tahun 2018

pengindraan sampai menghasilkan pengetahuan tersebut sangat dipengaruhi oleh intensitas perhatian dan persepsi terhadap objek. Sebagian besar pengetahuan seseorang diperoleh melalui indra pendengaran yaitu telinga dan indra penglihatan yaitu mata (Notoatmodjo, 2012). Teori juga menyatakan bahwa kurangnya informasi dan pengetahuan seseorang akan dapat berdampak terhadap pembentukan sikap seseorang. Pengetahuan yang baik dapat mempengaruhi seseorang bersikap positif. Sebaliknya pengetahuan yang kurang dapat mempengaruhi seseorang itu bersikap negatif. Sikap merupakan reaksi atau respon seseorang yang masih tertutup terhadap suatu stimulus atau objek (Notoatmodjo, 2013). Pada masa remaja mereka itu cenderung memiliki sikap ingin tahu yang lebih besar, di mana mereka memiliki naluri yang sangat tinggi untuk coba-coba. Rasa ingin tahu yang lebih besar ini menyebabkan mereka itu lebih mudah terpengaruhi oleh kebiasaan seharihari di lingkungan tempat mereka bergaul. Sikap remaja zaman sekarang ini banyak yang melanggar normanorma yang telah ada, ketika remaja itu terpengaruh kedalam pergaulan yang tidak baik itu akan berdampak kepada sikap remaja itu sendiri, baik apa tidak nya sikap remaja itu. Ini berarti pasrasiswi itu melakukan hubungan seks bebas. Seks bebas adalah hubungan seksual secara bebas, tanpa di batasi oleh aturan aturan. Ini membuktikan bahwa masih kurangnya pengetahuan siswa tentang dampak negatife dari seks pranikah yang paling meresahkan masyarakat salah satunya adalah PMS.

\section{Rata-Rata Tingkat Sikap Tentang PMS Pada Siswa Kelas XI Di SMA Banuhampu Kabupaten Agam Sebelum Dilakukan Penyuluhan}

Berdasarkan tabel 4.2 didapatkan bahwa rata-rata tingkat sikap tentang PMS sebelum dilakukan penyuluhan pada kelompok Eksperimen yaitu sebesar 5,57 dengan standar deviasi 1,50 sedangkan ratarata pada kelompok kontrol yaitu sebesar 6,16 dengan standar deviasi 1,25. Dari data diatas dapat terlihat bahwa bahwa rata-rata tingkat sikap tentang PMS pada siswa kelas XI di SMA Banuhampu Kabupataen Agam sebelum dilakukan penyuluhan antara kelompok kontrol dan eksperimen tidak terlalu jauh berbeda. Hal ini dapat dilihat bahwa dengan tidak adanya penyuluhan seseorang akan memiliki pengetahuan seseorang sehingga dapat berpengaruh pada sikap. Hal diatas sejalan dengan teori Notoadmojdo, (2013) bahwa kurangnya informasi dan pengetahuan seseorang akan dapat berdampak terhadap pembentukan sikap seseorang. Pengetahuan yang baik dapat mempengaruhi seseorang bersikap positif. Sebaliknya pengetahuan yang kurang dapat mempengaruhi seseorang itu bersikap negatif. Sikap merupakan reaksi atau respon seseorang yang masih tertutup terhadap suatu stimulus atau objek (Notoatmodjo, 2013).Menurut teori sikap merupakan keteraturan tertentu dalam hal perasaan (afeksi), pemikiran (kognisi), dan predisposisi tindakan (konasi) seseorang terhadap suatu aspek dilingkungan sekitarnya (Azwar, 2012). Sikap merupakan evaluasi umum yang dibuat manusia terhadap dirinya sendiri, orang lain, obyek atau isue (Wawan A \& Dewi M, 2011). Pada masa remaja mereka itu cenderung memiliki sikap ingin tahu yang lebih besar, di mana mereka memiliki naluri yang sangat tinggi untuk coba-coba. Rasa ingin tahu yang lebih besar ini menyebabkan mereka itu lebih mudah terpengaruhi oleh kebiasaan sehari-hari di lingkungan tempat mereka bergaul. Sikap remaja zaman sekarang ini banyak yang melanggar norma-norma yang telah ada, ketika remaja itu terpengaruh kedalam pergaulan yang tidak baik itu akan berdampak kepada sikap remaja itu sendiri, baik apa tidak nya sikap remaja itu. 
Fuad A, Batubara S : Pengaruh Penyuluhan Terhadap Pengetahuan dan Sikap Tentang Penyakit Menular Seksual (PMS) Pada Siswa KElas XI IPA SMA Banuhampu Kabupaten Agam Sumatera Barat Tahun 2018

\section{Rata-Rata Tingkat Pengetahuan Tentang PMS Pada Siswa Kelas XI Di SMA Banuhampu Kabupaten Agam Sesudah Dilakukan Penyuluhan}

Berdasarkan tabe 14.3 didapatkan bahwa rata-rata tingkat pengetahuan tentang PMS sesudah dilakukan penyuluhan pada kelompok Eksperimen yaitu sebesar 65,94 dengan standar deviasi 9,91 sedangkan rata-rata pada kelompok kontrol yaitu sebesar 58,37 dengan standar deviasi 12,70. Dalam penelitian ini setelah dilakukan penyuluhan tentang PMS dapat meningkatkan pengetahuan seseorang dengan selisih nilai rata-rata pada 9,73 dari sebelum dilakukan penyuluhan. Hal ini berkaitan erat bahwa penyuluhan dapat memberikan informasi. Sesuai dengan teori yang menyatakan bahwa kegiatan penyampaian atau menerangkan pesan yang berisi informasi, gagasan, emosi dan keterampilan dari satu lembaga, kelompok dan individu lain, (komunikan) dengan tujuan mengubah pengetahuan dan kesadaran (Damanik, 2007). Penyuluhan merupakan terjemahan dari konseling yaitu bagian dari bimbingan, baik sebagai layanan maupun sebagai teknik (Machfoedz, 2007). Dalam penelitian ini dilakukan penyuluhan tentang Penyakit Menular Seksual, penyuluhan yang dilakukan berupa penyuluhan yang berkaitan dengan kesehatan, dimana menurut teori Penyuluhan kesehatan adalah kegiatan pendidikan kesehatan,yang dilakukan dengan menyebarkan pesan, menanamkan keyakinan, sehingga masyarakat tidak saja sadar, tahu dan mengerti, tetapi juga mau dan bisa melakukan suatu ajaran yang ada hubungannya dengan kesehatan (Machfoedz, 2007)

\section{KESIMPULAN}

Berdasarkan hasil penelitian dan pembahasan pada bab $\mathrm{V}$ tentang pengaruh penyuluhan terhadap pengetahuan dan sikap tentang Penyakit Menular Seksual pada siswa kelas XI di SMA Banuhampu Kabupaten Agam Sumatera Barat Tahun 2018 yang telah dipaparkan sebelumnya maka dapat di tarik kesimpulan sebagai berikut:

1. Sebelum dilakukan intervensi pada tingkat pengetahuan ditemukan nilai rata-rata kelompok eksperimen dan kontrol sedikit perbedaan dimana nilai rata-rata kelompok kontrol lebih tinggi dari pada kelompok eksperimen.

2.Sebelum dilakukan intervensi pada tingkat sikap ditemukan nilai ratarata pada kelompok eksperimen dan kelompok kontrol sedikit perbedaan dimana rata-rata kelompok kontrol lebih tinggi dari pada kelompok eksperimen.

3.Setelah dilakukan intervensi pada tingkat pengetahuan ditemukan peningkatan nilai ratarata pada kelompok eksperiment. Sedangkan pada kelompok kontrol sedikit terdapat peningkatan.

4.Setelah dilakukan intervensi pada tingkat sikap ditemukan peningkatan nilai rata-rata pada kelompok eksperimen. Sedangkan pada kelompok kontrol sedikit terdapat peningkatan.

5.Didapatkan pengaruh yang bermakna antara tingkat pengetahuan sebelum dan sesudah dilakukan penyuluhan tentang PMS pada kelompok eksperiment dan tidak terdapat pengaruh pada kelompok kontrol.

6.Didapatkan pengaruh yang bermakna antara tingkat sikap sebelum dan sesudah dilakukan penyuluhan tentang PMS pada kelompok eksperiment dan tidak terdapat pengaruh pada kelompok kontrol.

\section{DAFTAR PUSTAKA}

Atikunto, S. 2010. Prosedur Penelitian, Suatu Pendekatan Praktek Jakarta: Rineka Cipta Ayu, I. Chandra 2009. Memahami Kesehatan Reproduksi Wanita. Jakarta: EGC.

Azwar, S. 2013. Reliabelitas dan Validitas. Yokyakarta:Pustaka Pelajar 
Fuad A, Batubara S : Pengaruh Penyuluhan Terhadap Pengetahuan dan Sikap Tentang Penyakit Menular Seksual (PMS) Pada Siswa KElas XI IPA SMA Banuhampu Kabupaten Agam Sumatera Barat Tahun 2018

Brooker,C. 2014. Kapita Selekta Kuesioner Pengetahuan Dan Sikap. Dalam Penelitian Kesehatan.Jakarta: Salemba Medika.

Caple, C. S. T, dkk, 2010. Penyakit Menular Seksual: Faktor Resiko. Kumulatif Indek Perawat: Panduan Keperawatan.

Daili. 2009. Infeksi Menular Seksual. Jakarta : Fakultas Kedokteran Universitas Indonesia.

Departemen Kesehatan Republik Indonesia. 2016. Usia Remaja Produktif. Jakarta: Departemen Kesehatan RI

Dinas Kesehatan Kota Padang. 2018. Profil Kesehatan Kota Batam Tahun 2018. Kota Batam.

Dorland, W.A.N. 2015. Kamus Kedokteran Dorland, ed. 29. Jakarta: Elsevier.

Nurmusazanah ,E .2015. Pengaruh Pendidikan Kesehatan Tentang Penyakit Menular Seksual (PMS) melalui Media Booklet Terhadap Tingkat Pengetahuan, Perilaku, Dan Daya Terima Siswi Di Smk Surakarta. Naskah publikasi.Diakses : 20 Juli 2018

Hastono, S.P, dkk. 2014. Statistik Kesehatan. Jakarta: Rajawali Press.

Hidayat, A. 2007. Riset Keperawatan Dan Teknik Penulisan Ilmiah.ed.2 Jakarta : Salemba Medika.

Johariyah, A. Mariati,T. 2018. Efektivitas Penyuluhan Kesehatan Reproduksi Remaja Dengan Pemberian Modul Terhadap Perubahan Pengetahuan Remaja. Jurnal Manajemen Kesehatan RS. Dr. Soetomo. Vol 4. No 1.Yogyakarta. www.jurnal.stikesyrsds.ac.id

Machfoedz, I. Suryani, E. 2009. Pendidikan Kesehatan. Bagian Dari Promosi Kesehatan. Cetakan Ke tujuh. Yogyakarta: Fitramaya.

Marmi, S.St. 2013. Kesehatan Reproduksi. Yogyakarta : Pusat Belajar.

Matteucci, R.S.T, dkk. 2010. Penyakit Menular Seksual Pada Wanita. Kumulatif Indek Perawat: Panduan Keperawatan.

Notoatmodjo, S. 2012. Promosi Kesehatan Dan Ilmu Prilaku. Jakarta: Rineka Cipta.

Putri, 2014. Pengaruh Penyuluhan Terhadap Pengetahuan Dan Sikap Tentang Penyakit Menular Seksual Pada Remaja di SMA Negeri 2 Banguntapan Bantul Yogyakarta. Naskah publikasi. Diakses : 20 Juli 2018

Rumengan, J. 2008. Metodologi Penelitian Kesehatan. Bandung: Citapustaka Media Perintis.

Said, A. Budiman, J.A. Strategi mengajar Multiple Intelegences Mengajar sesuai kerja otak dan gaya belajar siswa. Jakarta: Prenada Media Groub.

Setia, R, dkk. 2015. Obstetri Williams. Volume Ke dua. Jakarta: EGC.

Purwoastuti, E.Th, dkk. 2015. Ilmu Obstetri Dan Ginekologi Sosial Untuk Kebidanan. Jakarta: Pustaka Baru Pess.

Wardhani, D.T. 2012. Perkembangan dan seksualitas remaja. Jurnal Sosio Informa, Kajian Permasalahan Sosial dan Usaha Kesejahteraan Sosial. Vol 17, No 3 (184-191). Puslitbangkesos

Widyastuti, Y. Rahmawati,A. Purnamaningrum,Y :2009. Kesehatan Reproduksi. Yogyakarta:Fitramaya.

\begin{tabular}{|l|l|l|l|}
\hline Accepted Date & Revised Date & Decided Date & Accepted to Publish \\
\hline 28 Juni 2020 & 01 Juli 2020 & 9 Juli 2020 & Ya \\
\hline
\end{tabular}

